\title{
Code-Switching Serves a Euphemism
}

\author{
Rusdiah \\ Muslim University of Indonesia
}

\begin{abstract}
Euphemism exists in code-switching, it is used by the Indonesian speakers. The objective of this research is to investigate euphemisms used by the Indonesian speakers in their utterances in Bahasa Indonesia (Indonesian language), local languages, and foreign languages (English and Arabic). The research was descriptive by collecting data from the original speech of the speakers' utterances, through recording, and note-taking. The result of the research indicates that there are 30 euphemism in words or phrases found in the Indonesian speakers, they are (datum no. 6), five euphemisms from Bahasa Indonesia (data no. 2, 4, 13, 15, 25), 11 euphemisms from English language (data no. 5, 7, 9, 12, 17, 19, 20, 23, 24, 27, 30) and 13 euphemisms in Buginese language (data no. $1,3,8,10,11,14,16,18,21,22,26,28,29)$.
\end{abstract}

Keywords: euphemism, code-switching

\section{Background}

Language is an intimate part of social identity. Any language varieties used by speakers during natural communication takes place as a legitimate form of expresion. In all school settings, language always becomes the medium and sometimes the object of formal study. Often, teachers have a particular responsibility for certain aspects of language instruction, which includes teaching native language literacy skills and skills in a second language.

In many of the world's bilingual communities, and the accepted paradigm nowadays for the linguistic study of bilingualism is code-switching. When two or more languages exist in a community, speakers sometimes switch from one language to another. This phenomenon known as code-switching (Sridhar in McKay and Hornberger, 1998:47). Many scholars have studied extensively about the patterns of code switching and the reasons for code switching.

We can find that in Asia, many countries use two languages, for example Malaysia, Philippines, Singapore, even Indonesia which use two even more languages to communicate. People who use two or more languages are called the agent of two languages based on the research of bilingualism. Linguists found that the use of two different languages together would automatically influence one another.

The second language learning environment encompasses everything the language learner hears and sees in the new language. It may include a wide variety of situations such as exchanges in restaurants and stores, conversations with friends, reading street signs and newspapers, classroom activities, as well as in broadcast, etc.

This characterization of language learning entails the successful mastery of steadily accumulating structural entities and organizing this knowledge into coherent structures which lead to effective communication in the target language. If this is the case, then we would expect that well-formed accurate and complete target language structures would, one after another, emerge on the learner"s path towards eventual mastery of the language. If the learner went on to master the language, we could, in principle, tabulate the expansion of his/her repertoire up to the point where all of the well-formed structures of the target language had been accounted for (Hoffman, 1991:17).

In the modern world, and particularly in the focus on most scholarship discussion, code-switching appears as a largerly oral phenomenon. Such discussion can emphasize how codeswitching often occurs when bilinguals shift topic of conversations, for example, or introduce new interlocutor to their conversation, or exercise self-expression and creativity.

From earlier and more recent research we know that codeswitching is related to and indicative of group membership in particular types of bilingual speech communities, such that the regularities of the alternating use of two or more languages within one conversation may vary to a considerable degree between speech comminities. We also know that intrasentensial code-switching, where it occurs, is constrained by syntactic and morphosyntactic considerations which may not be of a universal kind.

We frequently find that many Indonesian speakers switch their English into Bahasa Indonesia,or vice versa even to local languages. These phenomenon occur because language as a symbol of important human behaviour and component in group identity. Code-switching is not only a phenomenon in a society, in which use more than one language, but is a need in this society as well. Speaker switches his/her code to clarify,emphasize, translate the meaning, to quote, to be more understand, can 'i be able to say in the language is being used, to be more understand, etc.

\section{Literature Survey}

Code-switching, which may be briefly defined as the alternation between two (or more) languages, has been receiving growing attention in recent years. Far from being viewed as a random phenomenon, it has come to be seen as a highly purposeful activity. However, the majority of extant studies have been conducted in authentic bilingual speech communities. Grosjen's theory (in Surbakti and Anggraini, 2013) about perspective of functions of code-switching are: code-switching serves referential function, directive function, expressive function, phatic function, metalinguistic function and poetic function. The use of euphemism has traditionally been common in subject areas in which people do not like talking directly. According to Fujita in Nilawati 


\section{International Journal of Science and Research (IJSR) \\ ISSN (Online): 2319-7064}

Index Copernicus Value (2013): 6.14 | Impact Factor (2014): 5.611

and Ardi (2012) there are positive and negative euphemism. The positive one is inflate and magnify. It makes the euphemized items seem altogether grander and more important than they really are. It includes imposing job titles adopted to bolster one ss self-image or impress one "s friends and acquaintances. For example, "territory manager" in place of "salesmen" an pramuniaga to replace penjaga toko "shop keeper".

Characteristic of euphemism as a language phenomenon has some special characteristic. To succeed in learning, learners of language should pay much attention to the following features of euphemism.. Firstly, in almost all cultures there are things strongly forbidden by social customs. Generally, people try to avoid mentioning taboos directly,. When the taboos (the forbidden things) have to be referred to, it is likely that people tend to substitute expressions that sound better. So there are euphemisms in almost every language. For example: the word ,bugilee. In Indonesia ,bugile is taboo word because it"s impolite and unusual with the culture in Indonesia. But may be in America it is taboo those words is not really of their culture or their lifestyle. Secondly, is culture specificity. The universal existence of euphemism in language does not mean that euphemisms are identical in different languages. Euphemism has close relevance to culture. Notions and norms upheld by people in different cultures are not necessarily the same. As a result the taboos in different cultures are not necessarily the same what is necessary to be euphemized in one question about age of one $\mathrm{s}$ marital status or prices of one $\mathrm{s}$ belongings. (Nilwati and Ardi,2014). People use euphemisms to get rid of the negative meaning or connotation the word or topic. These include sex, death, killing, crie, disease and different functions of human body. People use euphemisms to protect themselves and others from the harsh reality of life. People also use euphemism to cover up or disguise motives and events. For example, the phrase a strategic movement to the rear sounds less humiliating than retreat. A preemptive strike is much more likely acceptable than a sneak attack (CliffsNotes, 2014). The following are the examples of euphemism:

\begin{tabular}{|c|c|}
\hline Euphemism & Denotation \\
\hline pass away & die \\
indisposed & sick \\
economically deprived & poor \\
low-income dresses & cheap clothes \\
dignified marton & old woman \\
negative savings & debts \\
disabled & cripple \\
retirement pension & old-age pension \\
unemployment benefit & dole \\
take industrial action & go on strike \\
chemical dependency & duty addiction \\
under the weather & ill \\
low iq/slow & stupid \\
companion animal & pet \\
disposal officer/ & dustman/ \\
sanitation engineer & cleaning service \\
correctional facility & prison \\
relocation centre & prison camp \\
unmotivated & lazy \\
the call of nature & the urge of to urinate \\
freedom fighters & rebels \\
\hline & \\
\hline &
\end{tabular}

According to Ruth Wajnryb that Euphemisms have a short self life-once the stigma of the original cathes up to them, the battery that runs the euphemistic device goes flat. (Expletive Deleted: A Good Look at Bad Language, 2005).

R.W. Holder in his Dictionary of Euphemisms (2007) notes that in speech or writing, we use euphemism for dealing with taboo or sensitive subjects. It is therefore the language evasion, hypocrisy, prudery, and deceit.

Fromkin (1990:269) defines euphemism as a word or phrase that replaces a taboo word or serves to avoid frightening or unpleasant subject. He also says that euphemism in used because there is a prohibition on the use of, mention of, or association with particular objects or person.

\section{Methods}

The subject of the research covered Indonesian speaker, which are elected randomly. The population is the formal and non-formal converastions taken from the speakers. To determine the sample, the researcher took fifty euphemism in code-switching by using purposive sampling technique.

The data were collected through recording, note-taking, and questionnaires. Most of the data had been collected through recording the original speech from the speaker. The researcher also wrote down directly of euphemism in their code-switching.

Data had been analysed by using descriptive method. It aimed to find and describe The extent to which speakers used euphemisms in their code swithingeuphemism codeswitching. The procedure of analysing data: (1) the recording speech is firstly transcribed and then sorted out the euphemisms in code-switching from these transcribed data (2) the euphemisms in code-switching discourses are then put in a table.

\section{Results and Discussion}

Euphemisms in code-switching are found in the speakerse utterances are in formal and informal situation .The utterances are in Bahasa Indonesia (Indonesian language), local (Buginese and Makassarese language) and English language. The following are the extent to which speaker used euphemisms in their code-switching:

1) Sarung yang seperti itu MASEMPO bu, yang lain saja Translation: The sarong like that is CHEAP mom, please take other

2) Excuse me mom, KE BELAKANG sebentar. Translation: Excuse me mom, I am going to go back just for a minute

3) Kenapa tidak barengan masuk ke masjid, MACAREPA ki kah?

Translation: Why don't you get in to the mosque together, you get your period, don't you? are you DIRTY, aren't you?

4) Our boss MEMBERSIH-BERSIHKAN orang yang malas, that's right?

That's right?

Translation: Our boss CLEANS the people who are lazy, that's right doesn't he? 


\section{International Journal of Science and Research (IJSR) \\ ISSN (Online): 2319-7064}

Index Copernicus Value (2013): 6.14 | Impact Factor (2014): 5.611

5) Tidak masalah ma, DRESS CODE nya pada acara kawinan ini warna merah

Translation: There is no problem mam, its DRESS CODE at this wedding is red

6) Jangan ditarik itu tali kuat-kuat AKLAMPAI SALLANG Do not be pull that rope strongly GO AFTERWARDS

Translation: Don't pullthat rope strongly, it will GO AFTERWARDS

7) Jurnal-jurnal yang kualitas nya merupakan jurnal QUESTIONABLE

Translation: The journals with questionable quality

8) KalauIDIbisa melakukan itu maka akan terjadi bias pada standarinternasional.

Translation: If you do that, it could biased the international standards

9) Kita mau sekali agar mahasiswa-mahasiswa mempunyai STANDARD

Translation: We really dream that that students could have LITERACY STANDARD

10) Mampirki sejenak MABBURA-BURA di rumah ku walapun sedikit, ajak teman-teman

Translation: Please call atto my house for MABBURABURA "TO EAT" sometimes, although a little, take your friends with you!

11) Jangan selalu memuji dia akan MALOPPO ULUnna Translation: Do not always commend her, she will feel BIGGER HEAD

12) Semua jurnal akan memilkiTRADE MARK untuk bisa berterima

Translation: All journals will have TRADE MARK in order to be accepted

13) Bahasa Jawa nya NGEGANG begitulah seperti itu. Translation: It's Javanese language GANK is like that

14) Kalau kalian kuliah belajar yang tekun, jangan seperti orang yang PAKKALA AJU

Translation: If you attend lecture, you should study hard, do not act like a CARPENTER

15) Masussa memeng i kasina apa elo di AMPUTASIaje na Translation: It is truly pitiful for him because his legs will be amputated

16) Please tell him that he must be serious, DIPIKULsemua itu tanggungjawab yang ada padanya

Translation: Please tell him that he must be serious, he need to be responsible for all duties he had.

17) Baru saja saya mainkan yang cerita lain eh.. ternyata jagoan nya GAME OVER

Translation: I have been just played that different story eh.... Its champion GAME OVER

18) It doesn't matter, he can be treated as KELUARGA PRASEJAHTERA

Translation: It doesn't matter, he can be treated as PREPROSPEROUS FAMILY

19) EYE CONTACT itu tidak melihat di mana hidup kita penuh dengan tantangan

Translation: That EYE CONTACT does not see where our lives are full with challenges

20) Sebaiknya memang harus kita antisipasi sebelum banyak beredar ADULT MOVIE

Translation: It is better to quickly anticipate the spreading of the ADULT MOVIE

21) The third agenda is speeches, the first speech will be delivered by BAPAKProf. Dr.

Translation: The third agenda is speeches, the first speech will be delivered by Bapak Prof.Dr.

22) She is not so well, BERISI mi makanya dia tampak loyo-loyo.

Translation: She is not very well, she is FULFILLED so she looks very tired

23) Santaimiki saja sayang urusan kita bakalan menjadi GOLDEN PEARL

Translation: To be patient honey, our business will become GOLDEN PEARL

24) Where are you going to bu? PENYEMANGAT ta semua cantik

Translation: Where are you going to madam? all of your SUPPORTERS are beautiful

25) It es $^{\circ}$ difficult to manage the program, DISUNAT mungkin uang nya

Translation: It's difficult to manage the program, maybe it relates to money issueTO BE CIRCUMSISED

26) Ibu ku pulang kampung apa MAPEDDI LADDE'T tidak ada apa-apa.

Translation: My mother went to the village (went home) because she is VERY HURTFUL due to having nothing

27) Saya diasuh oleh ibu ku yang SINGLE PARENT Translation: I was grown up by my SINGLE-PARENT mother

28) Kenapa ibu kirim sms seperti itu.. MALASA-LASAI mungkin

Translation: Why did mam send sms like that, she may be get SICK

29) Bagaimana hasil ikan mu hari ini, MAWASA-WASA muakah?

Translation: How is your fish product today, it is WET, isn't it?

30) Kita tauji toh? kalau dia alumni yang juga punya HARD OF VISION PROBLEM

Translation:Do you know,? he is an alumnus who also has the deficiency of HARD OF VISION PROBLEM

Table: The extent to which speakers used euphemisms in code switching

\begin{tabular}{|c|c|c|}
\hline $\mathrm{NO}$ & EUPHEMISM & DENOTATION \\
\hline 1 & Masempo“cheap" & Dekgaga "no more" \\
\hline 2. & Ke belakang " to back" & WC \\
\hline 3 & Macarepa "dirty" & Maddara "menstruation" \\
\hline 4 & $\begin{array}{l}\text { Membersih-bersihkan } \\
\text { clean", }\end{array}$ & $\begin{array}{l}\text { Memecat } \\
\text { "to discharge" }\end{array}$ \\
\hline 5 & Dress code & Uniform dress \\
\hline 6 & Aklapai sallang "go afterwards" & Tappu "broken off” \\
\hline 7 & Questionable & Bad quality \\
\hline 8 & Idiec you" & Iko "you" \\
\hline 9 & Standard literacy & Better quality \\
\hline 10 & Mabbura-bura "to eat: & Manre "to eat" \\
\hline 11 & Maloppo ulu "big head" & "to boast" \\
\hline 12 & Trade mark & Legality \\
\hline 13 & Ngegank " grouping" & berkelompok "grouping" \\
\hline 14 & Pakkala aju "carpenter" & Tau makuttu "a lazy man” \\
\hline 15 & Amputasi ,amputation” & Memotong "to cut" \\
\hline 16 & Dipikul "carry a load" & Responsibility \\
\hline 17 & Game over & Died \\
\hline 18 & $\begin{array}{l}\text { Keluarga prasejahtera } \\
\text { "preprosperous family" }\end{array}$ & $\begin{array}{l}\text { Keluarga miskin } \\
\text { "wealthy family", }\end{array}$ \\
\hline 19 & Eye contact & Point of view \\
\hline 20 & Adult movie & Pornography \\
\hline 21 & Bapak "sir" & Tuan "mister" \\
\hline 22 & Berisi "fulfilled" & Hamil "pregnant" \\
\hline
\end{tabular}

Volume 5 Issue 1, January 2016 www.ijsr.net 
International Journal of Science and Research (IJSR)

ISSN (Online): 2319-7064

Index Copernicus Value (2013): 6.14 | Impact Factor (2014): 5.611

\begin{tabular}{|l|l|l|}
\hline 23 & Golden pearl & The best \\
\hline 24 & Penyemangat "supporter" & Anak-anak "children" \\
\hline 25 & Disunat "to be cut" & Korupsi "corruption" \\
\hline 26 & mapeddi ladde "e "very hurtful" & Kasi-asi “poor man" \\
\hline 27 & Single parent & Widow \\
\hline 28 & Malasa-lasai " sick" & Tojangeng "a little crazy" \\
\hline 29 & Mawasa-wasa "wet" & Maega "a lot of" \\
\hline 30 & Hard of seeing & Blind \\
\hline
\end{tabular}

\section{Conclusion}

The research concludes that there are 30 euphemisms are found in the speakers ${ }^{\text {ee }}$ code-switching, they are consist of: one euphemism from Makassarese language (datum no. 6), five euphemisms from Bahasa Indonesia (data no. 2, 4, 13, 15, 25), 11 euphemisms from English language (data no. 5, $7,9,12,17,19,20,23,24,27,30)$ and 13 euphemisms in Buginese language (data no. 1, 3, 8, 10, 11, 14, 16, 18, 21, $22,26,28,29)$.

\section{References}

[1] Adebola, Otemuyiwa Abosede. 2011. Code-switching and its Literacy Effects on the Acquisition of English Language by Yoruba / English Language Bilingual. Journal of Education and Practice, 2(5):65-73.

[2] Allan, Keith and Kate Burridge. 1991. Euphemism and Dysphemism. Oxford:Oxford University Press.

[3] Auer, Peter.2002. Code Switching in Conversation. London \& New York: Routledge.

[4] Barnard, Roger and Mclellan, James. 2013. Codeswitching in University English-Medium Classes. UK: Multilingual Matters

[5] Bloomfield, L. 1933. Language. Chicago: Holt Rinehalt and Winston.

[6] Burridge , K. Kuphemisms. http://tedstalks.ted.com/video/TEDxSydnei-KateBurridge-Euphem, accessed on 7 October 2015.

[7] CliffsNotes.2014. Euphemisms. Houghton Mifflin Harcourt. www.cliffnotes.com . Accessed on 1 November 2014.

[8] Crystal, D. 1980. A first Dictionary of Linguistics and Phonetic. London: Andre Deutch.

[9] Fromkin, Victoria et al. 1990. An Introduction to Language, Second Australian Edition. Routledge

[10] Gulzar, Malik Ajmal.2010. Code Switching: Awareness about its Utility in Bilingual Classrooms.Bulletin of Education and Research vol.32 No. 2 pp. 23-44(on line) Allama Iqbal Open University. Islamabad - Pakistan. Downloaded on 31st December 2011

[11] Gumperz, John J. 1977. The Sociolinguistic Significance of Conversational Code-switching. RELC Journal 8

[12]---------- 1982. Conversational Code switching in Discourse Strategies Cambridge, England:Cambridge University Press.

[13] Halliday,M.A.K. Learning How to Mean:Exploration in the Development of Language. London: Edward Arnold

[14] Hamsa, Akmal. 2012. Eufemisme Dalam Bahasa Bugis. Fakultas Bahasa dan Sastra, Universitas Negeri Makassar. A topnotch Word Press.com site. https://akmalhamsa .wordpress.com Accesed on 28 Nopember 2015
[15] Hoffman, C. 1991. An Introduction to Bilingualism. Cambridge: Cambridge University Press.

[16]Hudson, R.A. 1987. Sociolinguistics. Cambridge: Cambridge University Press.

[17] Inuwa, Yusuf Nuhu,et al. 2014. Factor Motivating Code Switching Within the Social Contact of Hausa Bilinguals. IOSR Journal of Huanities and Social Science (IOSR-JHSS) 19 (3):43-49.accessed on 9 July, 2014.

[18] Jakobson, R. 1998. Codeswitching Worldwide. Berlin: Luderitz \& Bauer.

[19]Leech, Geoffrey. 1981. Semantics. Second Edition. Harmondsorth: Penguin Book

[20] Martinet,A. 1970. Elements de Linguistique Generale. Paris: Armand Colin

[21] Martin-Jones, M. 1998. Workingpapers in Urban Language and Literacies. Volume 10: Teaching and Learning Bilingually: A Survey of Recent Research. London: Kinge's College.

[22] Mc.Kay, Sandra. Lee \& Hornberger, Nancy H. 1996. Socilinguistic and Language Teaching. USA: Cambridge University Press.

[23] Myers, Carol - Scotton, 1996. The Handbook of Sociolinguistics. Malden, Massachusetts: Blackwell Publishers Ltd.

[24] Nichol, Mark. 2011. 7 Types of Euphemisms. Jurnal in Daily Writing Tipshttp://www.dailywritingtips.com/7types-of-euphemism/ . accessed on 27 October 2014.

[25] Nilwati and Ardi, Havid. 2012. Types of Euphemism Used by Male and Female Kerinciness Speakers. English Language and Literature E-Journal UNP ISSN 2302-3546. Accessed on 28 October, 2014

[26] Poplack, Shana. 1980. Sometimes I'll Start a Sentence in Spanish Y TERMINO EN ESPANOL' Toward a typology of Code-switching. CENTRO Working Papers 7. Centro de estudios Puertorriquenos

[27] Rusdiah. 2004. Conversational Code-Switching among Lecturers and Students. Unpublished Thesis. English Language Studies- Unhas. Makassar.

[28] Sert, Olcay, 2005. The Functions of Code Switching in ELT Classrooms. The Internet TESL Journal, Vol.IX, No.8. http://iteslj.org/ accesed on July 6, 2014

[29] Spolsky,B.1998. Sociolinguistics.Oxford:

Oxford University Press.

[30] Sumarsono.2009. Sociolinguistics. Yokyakarta: SABDA.

[31] Surbakti, Roandryo S.P. and Anggraini, Aghata Viti.2013. The President's Switch.Jurnal KOLITA 11. ISBN 978-602-8474-26-9.pp 207-2011. Jakarta: Pusat Kajian Bahasa dan Budaya Universitas Katolik Indonesia Atama Jaya.

[32] Uys, Dawid. 2010. The Functions of Teacher's Code Switching in Multilingual and Multicultural High School Classroom in the Siyanda District of the Northern Cape Province. Stellenbosch University http://en.wikipedia.org/wiki/Siyanda_District_Municipa lity. Accessed on 3rd January 201.

[33] Varzinskas, Kasparas. 2013. Euphemism and its Usage in Media. www.academia.edu/7046720/Euphemisms_and_Dysphe misms in Media

[34] Wardhaugh. Ronald. 1986. Introduction to Linguistics. USA: Mcgraw Hill, Inc. 


\section{International Journal of Science and Research (IJSR) \\ ISSN (Online): 2319-7064}

Index Copernicus Value (2013): 6.14 | Impact Factor (2014): 5.611

[35] Webster-Merriam Online. www.Merriam Webster .com. accessed on 5 Nopember, 2014.

[36] Wikipedia. http://en.wikipedia.org/wiki/Euphemism. accessed on 27 October 2014.

[37] Yassi. Abdul Hakim.2001. Indolish (IndonesianEnglish) toward a typology of Indonesian-English code switching. Journal 2ndyear, No.4. Makassar: Program Pacsasarjana Universitas Hasanuddin.

[38]----------------- 2003. Code-switching as A Communication Strategy in Indonesian-English Bilingual Discourse. Unpublished Dissertation. Makassar: Program Pasca Sarjana Universitas Hasanuddin.

[39]-------------------- 2010. Materi Kuliah Metode Penelitian Lanjutan. Makassar: Program Doctor Universitas Hasanuddin.

[40]--------------- 2011. Elites and Code Switching. Makassar: Pustaka Pena Press.

\section{Author Profile}

Rusdiah is an English teacher at Muslim University of Indonesia Makassar since 1993. She finished his bachelor degree (Dra.) on English Department of Faculty of Letters at Muslim University of Indonesia Makassar, Indonesia. In $2004 \mathrm{He}$ got his magister degree on Magister of Humaniora (M.Hum) on English Language Studies at Hasanuddin University, in Makassar, Indonesia, and in $2010 \mathrm{He}$ continued to study Linguistics with special interest on Sociolinguistics. Now she is writing his dissertation entitled „Euphemism as Motivating Factor in CodeSwitching ee under the supervisors of Prof. Dr. Abdul Hakim Yassi, Dipl.TESL, M.A and Prof. Dr. H. Hamzah A. Machmoed, M.A. 